\title{
Globalización y migración internacional: la experiencia latinoamericana
}

\section{Andrés Solimano}

Asesor Regional,

División de Desarrollo

Económico,

CEPAL

asolimano@eclac.cl
La primera fase de la globalización, desde aproximadamente 1870 hasta 1913, vino acompañada de grandes flujos migratorios desde Europa a los países del Nuevo Mundo. En contraste, en la segunda fase de la globalización de fines del siglo XX la migración internacional enfrenta, principalmente en los países desarrollados, regímenes de inmigración más restrictivos. En América Latina, durante la primera fase, Argentina fue el más importante receptor de migrantes europeos. Cerca de siete millones de europeos llegaron al país en ese período, en respuesta a las atractivas oportunidades económicas de la belle époque argentina de fines del siglo XIX e inicios del XX. En cambio, en las últimas décadas del siglo XX Argentina se transformó en país de emigración neta al resto del mundo, particularmente de personas de alto nivel educativo. Este artículo presenta estimaciones econométricas de los patrones migratorios hacia y desde Argentina en el siglo XX y analiza los determinantes de los flujos migratorios internacionales en América Latina en general, incluyendo los patrones de inmigración intrarregional, particularmente entre países limítrofes. 


\section{I}

\section{Introducción}

Los mercados internacionales de trabajo son un componente esencial del proceso de globalización. La primera fase de la globalización, desde alrededor de 1870 a 1913, se caracterizó por una considerable movilidad internacional de la población, a semejanza del libre movimiento de bienes y capital que caracterizó a ese período en el marco del patrón oro y de una política de aranceles bajos. Este proceso se interrumpió durante el período de desglobalización de 1914-1945, caracterizado por dos conflictos mundiales, la alta inflación de los años veinte, la crisis económica de los treinta y además por inestabilidad política. Tales acontecimientos interrumpieron la integración económica que se había venido desarrollando cada vez más en la economía mundial antes de 1914 y dieron origen a una larga era de políticas migratorias más restrictivas. En la segunda fase de la globalización, iniciada en las últimas décadas del siglo XX, tanto la movilidad del capital como el comercio internacional aumentaron considerablemente. Sin embargo, esto no puso fin a la segmentación de los mercados internacionales de trabajo ni a las restricciones a la migración de trabajadores no calificados y de migrantes pobres, principalmente en los países desarrollados, lo que contrasta con la movilidad internacional de que disfrutan actualmente las personas con mayor acervo de capital humano y financiero, como los expertos en informática, los ejecutivos y los inversionistas internacionales. ${ }^{1}$

Históricamente, las economías grandes de América Latina, como Argentina seguida por Brasil, recibieron corrientes migratorias de gran magnitud que caracterizaron la primera fase de la globalización de fines del siglo XIX y principios del XX. En esa época se produjo también una corriente simultánea de capital hacia varios países - Argentina, por ejemplo_ - para captar las oportunidades económicas que ellos ofrecían. A partir del decenio de 1920, la desaceleración de la economía argentina y las dificultades de América Latina para al-

\footnotetext{
${ }^{1}$ Véanse algunos estudios acerca de la migración de capital huma-
} no en Solimano (2002), Carrington y Detragiache (1998), y Haque canzar un nivel de desarrollo acorde con su potencial de recursos hicieron que la migración internacional proveniente de Europa disminuyera de manera considerable y prácticamente se detuviera a fines de la década de 1950 y comienzos de la de 1960.

Dentro de América Latina, la migración intrarregional obedeció a importantes diferenciales entre los niveles de ingreso per cápita de los países, en especial de los limítrofes. Por otra parte, los países latinoamericanos, encabezados por México, se convirtieron en la principal región de origen de los emigrantes a los Estados Unidos, tendencia que se acentuó en los decenios de 1980 y 1990 e inicios del siglo XXI.

En este artículo se estudia el efecto de la globalización, de las diferencias de ingreso por habitante entre países y de otros factores en la migración internacional, prestando particular atención a lo ocurrido en América Latina. Tras esta introducción, en la sección II se examinan las diferentes fases de globalización y desglobalización en la evolución de la economía mundial, y los patrones de migración desde y hacia América Latina, cubriendo aproximadamente los últimos 130 años. En la sección III se examina el rol de distintos determinantes económicos, sociales y políticos de la migración, como diferenciales salariales entre países, redes sociales de apoyo a migrantes, fases del ciclo económico, costos de migrar, políticas migratorias y regímenes políticos. En la sección IV se analiza el caso de Argentina, en el pasado un importante país receptor de migrantes del resto de América Latina, que conforme avanzó el siglo XX se transformó en país de emigración, particularmente de recursos humanos calificados, debido a sus múltiples crisis económicas, complicadas por ciclos de autoritarismo e inestabilidad política; asimismo, se presentan ecuaciones econométricas de migraciones desde y hacia Argentina. La sección $\mathrm{V}$ contiene algunas conclusiones. y Kim (1994). Un trabajo bastante anterior sobre el tema se puede
encontrar en Adams (1964). 


\section{II}

\section{La migración internacional desde}

\section{y hacia América Latina}

Las dos fases de globalización de fines del siglo XIX y de fines del siglo XX, así como la desglobalización del período 1913-1945, fueron acontecimientos económicos importantes que afectaron de modo significativo las corrientes migratorias a nivel mundial y particularmente a nivel latinoamericano. En esta sección se realiza un análisis de esas tendencias.

\section{La primera fase de globalización y la era de la migración masiva (desde alrededor de 1870 a 1913)}

Los especialistas en historia económica denominaron "primera ola de globalización" al período de libre comercio, libre movilidad del capital y predominio del patrón oro $^{2}$ en la economía mundial que se extendió desde cerca de 1870 a 1913. Este período se caracterizó también por amplias corrientes migratorias internacionales, lo que le valió el nombre de "era de la migración masiva" (Hatton y Williamson, 1998). Se estima que durante esos años aproximadamente 60 millones de personas abandonaron una Europa con escasos recursos naturales y con exceso de mano de obra, para dirigirse a países del Nuevo Mundo con recursos naturales abundantes y escasez de mano de obra, como Argentina, Australia, Brasil, Canadá, los Estados Unidos y Nueva Zelandia. Los migrantes provenían tanto de Inglaterra, Alemania y Francia como de la Europa "periférica" de esa época (los países escandinavos, España, Italia y Portugal, Polonia, Rusia, Rumania y los antiguos países del Imperio Austrohúngaro y del Imperio Otomano). Argentina fue el principal país de destino de los migrantes europeos a América Latina; allí llegaron cerca de siete millones de ellos, de los cuales unos cuatro millones regresaron a su país de origen. Uruguay, Cuba, México y Chile también recibieron un número considerable de migrantes en ese período.

Las políticas de inmigración de los países del Nuevo Mundo durante la primera fase de globalización ${ }^{3}$

\footnotetext{
${ }^{2}$ Véase un análisis del papel del patrón oro en este período y los siguientes en Eichengreen (1996).

3 Sobre políticas de inmigración en el Nuevo Mundo durante la primera fase de globalización véase principalmente Timmer y
}

fueron, en general, liberales. Algunos de estos países, entre ellos Argentina, establecieron oficinas en Europa destinadas a incentivar y atraer las corrientes migratorias que incrementarían la oferta de mano de obra y sostendrían una rápida expansión económica. Sin embargo, con posterioridad estas políticas se fueron haciendo paulatinamente más restrictivas, sobre todo en los decenios de 1910 y 1920. La discriminación étnica (en contra de los migrantes asiáticos, sobre todo los provenientes de China) se transformó en una práctica común en varios países receptores, especialmente anglosajones, del Nuevo Mundo.

Como se puede apreciar en el cuadro 1, en 18701913 la diferencial de ingresos per cápita entre los países de la Europa periférica, por un lado, y países del Nuevo Mundo como Estados Unidos, Canadá y Australia, por otro, era netamente favorable a estos últimos, lo que estimulaba la migración hacia esos países. En 1913, el mayor ingreso per cápita de Argentina, que excedía en 30\% a los de España e Italia, creaba un fuerte incentivo económico para emigrar hacia ese país. En el mismo año, el ingreso per cápita de Uruguay también superaba a los de España e Italia, mientras que el de Chile se encontraba casi al mismo nivel del de esos dos países europeos.

\section{Guerras, inestabilidad, crisis y desglobaliza- ción (1913-1945)}

El estallido de la primera guerra mundial interrumpió el avance de la primera fase de la globalización e integración de los mercados de trabajo a nivel internacional. En 1914 empezaron 30 años de inestabilidad económica y política, principalmente en Europa, durante los cuales se sucedieron la primera guerra mundial, la altísima inflación de los años veinte, la crisis económica de los treinta y la segunda guerra mundial. Esta serie de turbulencias redundó en políticas de inmigración cada vez más restrictivas. Estados Unidos estableció cuotas

Williamson (1996). Holloway (1977) y Solberg (1970) son fuentes más directas acerca de Brasil, y acerca de Argentina y Chile, respectivamente. 
CUADRO 1

Países de Europa, América Latina y otros países

de la OCDE: PIB per cápita, 1820-2000

(En dólares de 1990) ${ }^{a}$

\begin{tabular}{|c|c|c|c|c|c|c|c|c|}
\hline & \multicolumn{3}{|c|}{$\begin{array}{c}\text { Primera fase de globalización, } \\
\text { era de la migración masiva } \\
\end{array}$} & \multirow[b]{2}{*}{1950} & \multicolumn{3}{|c|}{$\begin{array}{l}\text { Segunda fase de globalización, } \\
\text { migración restringida }\end{array}$} & \multirow[b]{2}{*}{2000} \\
\hline & 1820 & 1870 & 1913 & & 1973 & 1990 & 1998 & \\
\hline \multicolumn{9}{|l|}{ Europa } \\
\hline Italia & 1117 & 1499 & 2564 & 3502 & 10643 & 16320 & 17759 & 19223 \\
\hline España & 1063 & 1376 & 2255 & 2387 & 8739 & 12210 & 14227 & 17392 \\
\hline Portugal & 963 & 997 & 1244 & 2069 & 7343 & 10852 & 12929 & 15295 \\
\hline Noruega & 1104 & 1432 & 2501 & 5463 & 11246 & 18470 & 23660 & 29523 \\
\hline Suecia & 1198 & 1664 & 3096 & 6738 & 13493 & 17680 & 18685 & 20532 \\
\hline Promedio & 1089 & 1394 & 2332 & 4032 & 10293 & 15106 & 17452 & 20393 \\
\hline \multicolumn{9}{|l|}{ América Latina } \\
\hline Argentina & & 1311 & 3797 & 4987 & 7973 & 6512 & 9219 & 8645 \\
\hline Brasil & 646 & 713 & 811 & 1672 & 3882 & 4924 & 5459 & 5594 \\
\hline Chile & & & 2653 & 3821 & 5093 & 6401 & 9756 & 9957 \\
\hline Colombia & & & 1236 & 2153 & 3499 & 4822 & 5317 & 5044 \\
\hline México & 759 & 674 & 1732 & 2365 & 4845 & 6097 & 6655 & 7087 \\
\hline Perú & & & 1037 & 2263 & 3952 & 2955 & 3666 & 3684 \\
\hline Uruguay & & 2005 & 3309 & 4660 & 4975 & 6473 & 8314 & 7790 \\
\hline Venezuela & & 569 & 1104 & 7462 & 10625 & 8313 & 8965 & 8440 \\
\hline Promedio & 703 & 1054 & 1960 & 3673 & 5606 & 5812 & 7169 & 7030 \\
\hline \multicolumn{9}{|c|}{ Otros países de la Organización de } \\
\hline \multicolumn{9}{|c|}{ Cooperación y Desarrollo Económicos (OCDE) } \\
\hline Australia & 517 & 3645 & 5715 & 7493 & 12759 & 17043 & 20390 & 22461 \\
\hline Canadá & 893 & 1695 & 4447 & 7437 & 13838 & 18933 & 20559 & 23682 \\
\hline Nueva Zelandia & 400 & 2704 & 5152 & 8453 & 12513 & 13825 & 14779 & 16068 \\
\hline Estados Unidos & 1257 & 2445 & 5301 & 9561 & 16689 & 23214 & 27331 & 29512 \\
\hline Promedio & 767 & 2622 & 5154 & 8236 & 13950 & 18254 & 20765 & 22931 \\
\hline
\end{tabular}

Fuente: Maddison (2001) y FMI (varios años).

a Ajustados por la paridad de poder adquisitivo.

a la inmigración en 1921 y 1924, con la consiguiente reducción de las corrientes migratorias procedentes de Europa. Los migrantes reaccionaron cambiando ese destino por Brasil y Argentina. Este último país recibió unos tres millones de europeos en el decenio de 1920, aunque alrededor de dos millones regresaron a su país de origen (Chiswick y Hatton, 2002). Paralelamente, la Unión Soviética adoptó medidas para restringir la emigración, lo que redujo su participación en las corrientes migratorias mundiales con destino a América.

\section{El período posterior a 1950, la segunda fase de globalización y las restricciones persistentes a la inmigración}

Con el fin de la segunda guerra mundial, la reconstrucción económica de Europa y el restablecimiento de las relaciones comerciales y de las inversiones a nivel internacional en la segunda mitad de la década de 1940 y principios de la de 1950, se inició un nuevo período de prosperidad económica mundial. La nueva política económica se basó en un régimen de tipos de cambio fijos entre las principales monedas, y los mercados de capital internacionales y la migración internacional permanecieron restringidos. Este ciclo de prosperidad y estabilidad se mantuvo hasta comienzos del decenio de 1970, cuando los países industrializados debieron enfrentar a la vez el alza repentina del precio del petróleo y el brusco fin del sistema de paridades cambiarias fijas de los acuerdos de Bretton Woods. Estas dos perturbaciones (shocks) inauguraron un nuevo período en la economía mundial. La aparición de un activo mercado financiero internacional en la década de 1970, que alcanzó su pleno desarrollo en la de 1990, dio un renovado impulso a la internacionalización económica. El fin del comunismo y la creciente liberalización del comercio y los flujos de capitales dieron mayor ímpetu a la segunda fase de globalización. Sin embargo, la 
integración de los mercados internacionales de trabajo ${ }^{4}$ se rezagó respecto de la creciente integración mundial de los mercados de bienes y de capital propia de esta segunda fase de globalización. Las políticas inmigratorias restrictivas, sobre todo para personas con baja calificación, siguen prevaleciendo en los países desarrollados.

Las corrientes migratorias hacia Argentina, el país de la región que más inmigrantes ha recibido, se reanudaron tras el fin de la segunda guerra mundial, a mediados del decenio de 1940, y se prolongaron hasta la segunda mitad de la década de 1950, cuando en Europa se inició una nueva etapa de expansión económica. En contraste, la economía argentina creció a ritmos modestos en la década de 1950, disminuyendo las oportunidades tanto para los inmigrantes como para los nacionales. En 1950, el ingreso per cápita de Argentina, Uruguay y Venezuela seguía siendo superior al de Italia, España y otros países de la Europa periférica, pero la diferencia se reducía cada vez más, y alrededor de 1970 esta relación se había invertido para Argentina y Venezuela. Como se verá en este estudio al analizar con mayor detenimiento el caso argentino, en la década de 1970 los principales incentivos económicos para migrar de Europa hacia Argentina prácticamente habían desaparecido. La migración en sentido contrario, de Argentina hacia España e Italia, marcó la pauta desde entonces (Solimano, 2003).

En la primera mitad del siglo XX las corrientes migratorias hacia América Latina provenientes de Europa coexistieron con la emigración desde varias naciones latinoamericanas hacia los Estados Unidos, Canadá y otros países desarrollados. La migración mundial a los Estados Unidos (cuadro 2) pasó de un millón de personas en la década de 1940, y dos millones y medio en la de 1950, a casi siete millones y medio, en promedio, en los decenios de 1980 y 1990 . Vale la pena destacar que mientras los inmigrantes que llegaron a los Estados Unidos en el siglo XIX eran en su gran mayoría europeos (alrededor de $88 \%$ del total de inmigrantes entre 1820 y 1920), el porcentaje de ellos disminuyó a 14\% en 1971-1998. En este período, la principal región de origen de la migración hacia los Estados Unidos fue América Latina, con un $46 \%$ de la inmigración total, seguida por Asia, con un 34\%. A nivel de países, durante un largo período de 179 años, entre 1820 y 1998 (cuadro 2), los principales países de origen de migrantes a los Estados Unidos fueron Méxi-

\footnotetext{
${ }^{4}$ Véase Abella (1997), Stalker (2000) y Solimano (2001).
}

co, Cuba y la República Dominicana en América Latina, Filipinas, China, Corea e India en Asia, y Alemania, Italia, el Reino Unido e Irlanda en Europa. ${ }^{5}$

\section{a) Migración intrarregional en América Latina}

Hemos señalado ya el importante efecto que tienen las diferencias internacionales de ingresos per cápita, en un marco dado de políticas de inmigración, sobre las corrientes migratorias. El cuadro 3 muestra diferencias significativas en el producto interno bruto (PIB) per cápita entre los países latinoamericanos en el período 1950-2000. ${ }^{6}$ En este período, el ingreso per cápita de Argentina más que duplicó, en promedio, el de Bolivia y el de Paraguay. Debido a tal disparidad, Paraguay y Bolivia se convirtieron en los dos principales países de origen de los migrantes latinoamericanos a Argentina (cuadro 4). El ingreso per cápita de Chile fue, en promedio, $65 \%$ mayor que el de Perú y $80 \%$ más alto que el de Ecuador, diferencia que se amplió en la década de 1990, sobre todo por la rápida expansión de la economía chilena durante casi todo ese decenio. Las diferencias de ingreso per cápita entre Venezuela y Colombia han disminuido con el menor crecimiento de la economía venezolana en las dos últimas décadas. También existen diferencias considerables entre los ingresos per cápita de Costa Rica y de Nicaragua, que se acentuaron debido a la paralización de la economía nicaragüense durante la guerra civil del decenio de 1980 y su muy débil desempeño posterior. La diferencia de niveles de ingreso entre la República Dominicana y Haití, por su parte, aumentó de manera significativa a partir del decenio de 1980 y durante el de 1990.

Es importante destacar aquí que las desigualdades de desempeño económico entre los países de América Latina, sobre todo entre aquellos con fronteras comunes, parecen haber originado considerables corrientes migratorias entre ellos. En el cuadro 5 se aprecia, para varios años censales, el número de extranjeros nacidos en la región y fuera de ella que residen en países latinoamericanos. De acuerdo con estos datos, Argentina

\footnotetext{
${ }^{5}$ Las corrientes migratorias representaron en promedio el $7 \%$ de la población total de los Estados Unidos en 1871-1920; este porcentaje disminuyó a 2,5\% en el último tercio del siglo XX. En lo que respecta a la inmigración ilegal, se estima que aumentó significativamente durante la década de 1990, pasando de 3,3 millones de personas en 1992 a 5 millones en 1996 (véase Solimano, 2001, cuadro 2). El principal país de origen de migrantes ilegales a los Estados Unidos es México. Otros importantes países emisores de migrantes ilegales son El Salvador, Guatemala, Haití, Honduras, Canadá y Filipinas.

${ }^{6}$ En este artículo las cifras del PIB se usan como equivalentes del ingreso per cápita.
} 


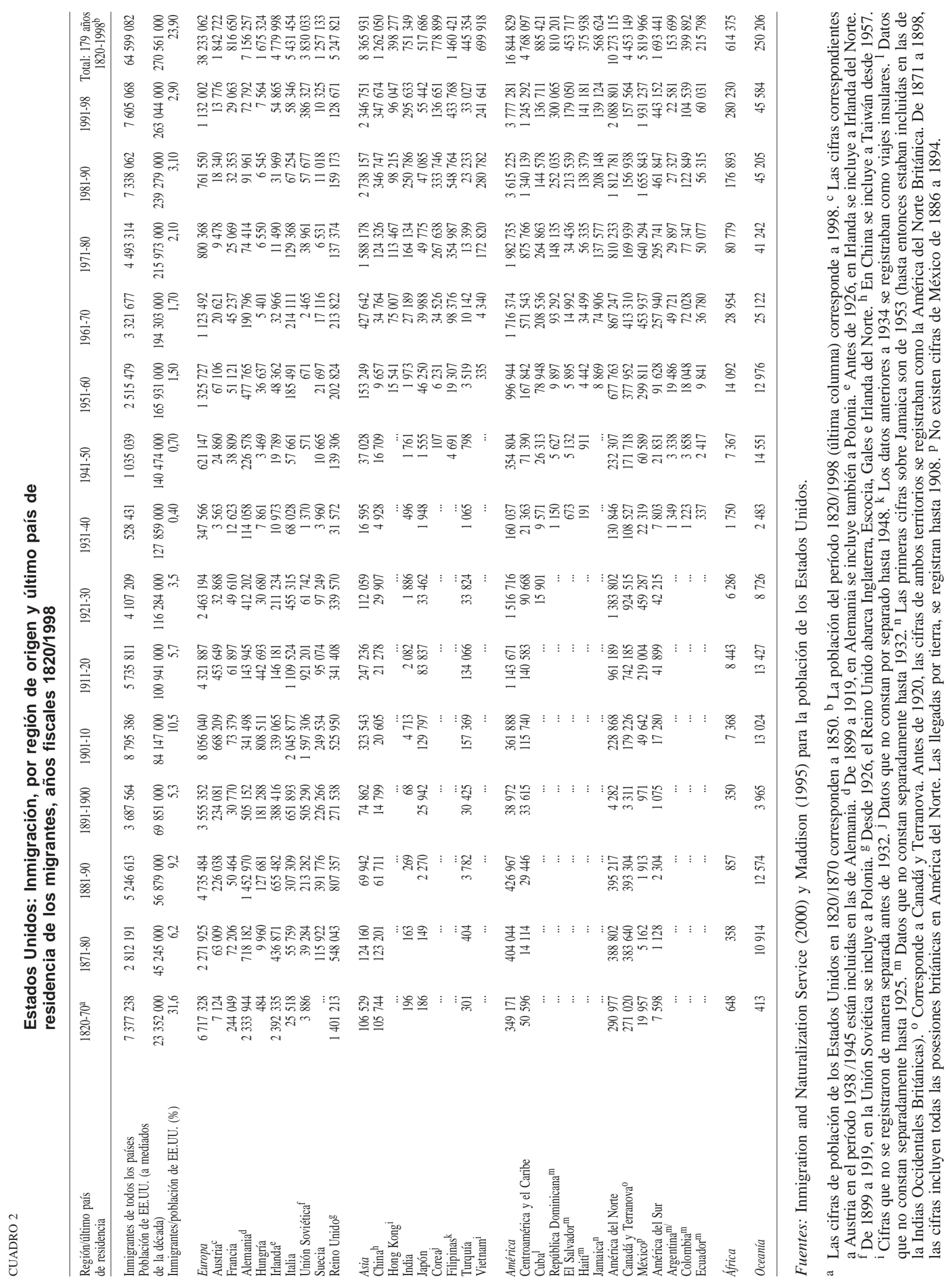


CUADRO 3

Países de América Latina: PIB per cápita, 1950-2000

(En dólares de 1990) ${ }^{a}$

\begin{tabular}{|c|c|c|c|c|c|c|c|c|c|c|c|c|c|}
\hline \multirow[b]{2}{*}{ Años } & \multicolumn{13}{|c|}{ Países } \\
\hline & Argentina & Bolivia & Chile & Colombia & $\begin{array}{l}\text { Costa } \\
\text { Rica }\end{array}$ & $\begin{array}{c}\text { Rep. } \\
\text { Dominicana }\end{array}$ & Ecuador & Haití & México & Nicaragua & Paraguay & Perú & Venezuela \\
\hline $1950-1954$ & 4920 & 1912 & 3998 & 2230 & 2134 & 1139 & 1990 & 1066 & 2478 & 1816 & 1533 & 2459 & 7898 \\
\hline $1955-1959$ & 5384 & 1673 & 4135 & 2404 & 2474 & 1292 & 2162 & 1053 & 2918 & 2052 & 1571 & 2754 & 9549 \\
\hline 1960-1964 & 5696 & 1669 & 4529 & 2581 & 2821 & 1409 & 2319 & 1003 & 3295 & 2245 & 1629 & 3261 & 9280 \\
\hline $1965-1969$ & 6541 & 1972 & 5049 & 2815 & 3371 & 1390 & 2596 & 888 & 3939 & 2793 & 1765 & 3675 & 9990 \\
\hline $1975-1979$ & 8112 & 2628 & 4790 & 3873 & 4691 & 2208 & 3705 & 1124 & 5433 & 2988 & 2543 & 4133 & 10947 \\
\hline $1980-1984$ & 7621 & 2393 & 5349 & 4233 & 4483 & 2413 & 3958 & 1224 & 6342 & 2167 & 3258 & 3971 & 9341 \\
\hline 1985-1989 & 7058 & 2098 & 5682 & 4540 & 4524 & 2436 & 3874 & 1099 & 5926 & 1758 & 3147 & 3695 & 8645 \\
\hline 1990-1994 & 7515 & 2264 & 7255 & 4953 & 4962 & 2566 & 4000 & 913 & 6295 & 1400 & 3270 & 3009 & 8881 \\
\hline $1995-2000$ & 8670 & 2405 & 9436 & 5262 & 5348 & 3124 & 4006 & 809 & 6550 & 1451 & 3182 & 3623 & 8752 \\
\hline $1950-2000$ & 6962 & 2135 & 5630 & 3656 & 3920 & 2004 & 3180 & 1012 & 4815 & 2147 & 2403 & 3455 & 9366 \\
\hline
\end{tabular}

Fuente: Maddison (2001) y FMI (varios años).

a Ajustados por la paridad de poder adquisitivo.

CUADRO 4

América Latina y el Caribe: Relación entre los PIB per cápita de países receptores y emisores de migración ${ }^{a}$

\begin{tabular}{|c|c|c|c|c|c|c|c|c|}
\hline \multirow{2}{*}{$\begin{array}{l}\text { Receptor } \\
\text { Emisor }\end{array}$} & \multicolumn{3}{|c|}{ Argentina } & \multicolumn{2}{|c|}{ Chile } & \multirow{2}{*}{$\frac{\text { Venezuela }}{\text { Colombia }}$} & \multirow{2}{*}{$\frac{\text { Costa Rica }}{\text { Nicaragua }}$} & \multirow{2}{*}{$\frac{\text { Rep. Dominicana }}{\text { Haití }}$} \\
\hline & Bolivia & Chile & Paraguay & Perú & Ecuador & & & \\
\hline $1950-1954$ & 2,58 & 1,23 & 3,21 & 1,63 & 2,01 & 3,54 & 1,18 & 1,07 \\
\hline $1955-1959$ & 3,23 & 1,30 & 3,43 & 1,50 & 1,91 & 3,97 & 1,21 & 1,23 \\
\hline 1960-1964 & 3,42 & 1,26 & 3,50 & 1,39 & 1,95 & 3,60 & 1,26 & 1,41 \\
\hline $1965-1969$ & 3,32 & 1,30 & 3,71 & 1,37 & 1,94 & 3,55 & 1,21 & 1,57 \\
\hline $1970-1974$ & 3,40 & 1,46 & 3,92 & 1,35 & 1,77 & 3,14 & 1,39 & 1,87 \\
\hline $1975-1979$ & 3,09 & 1,71 & 3,22 & 1,16 & 1,29 & 2,83 & 1,62 & 1,97 \\
\hline 1980-1984 & 3,19 & 1,43 & 2,34 & 1,35 & 1,35 & 2,21 & 2,07 & 1,97 \\
\hline 1985-1989 & 3,37 & 1,25 & 2,25 & 1,56 & 1,46 & 1,91 & 2,61 & 2,22 \\
\hline 1990-1994 & 3,31 & 1,04 & 2,30 & 2,41 & 1,81 & 1,79 & 3,55 & 2,86 \\
\hline $1995-2000$ & 3,60 & 0,92 & 2,73 & 2,60 & 2,36 & 1,66 & 3,69 & 3,86 \\
\hline $1950-2000$ & 3,26 & 1,28 & 3,05 & 1,65 & 1,80 & 2,80 & 2,01 & 2,04 \\
\hline
\end{tabular}

Fuente: Maddison (2001) y FMI (varios años).

a Relación basada en el PIB per cápita en dólares de 1990, ajustados por la paridad de poder adquisitivo.

ha sido el principal receptor de migrantes nacidos en otros países latinoamericanos, tanto en números absolutos como en proporción a su población, aunque la tendencia es decreciente. De hecho, el número de extranjeros residentes en el país ha venido bajando de manera sostenida, de unos 2.5 millones $(12,7 \%$ de la

\footnotetext{
${ }^{7}$ El censo de 1991 es el último para el que existen resultados publicados.
}

población) en 1960 a alrededor de 1.6 millones (4,9\%) en $1991 .^{7}$ Otro país en el cual los extranjeros residentes también son numerosos es Venezuela, donde pasaron de casi 600 mil en 1971 a más de un millón en 1990. En el resto de los países incluidos en el cuadro 5 el porcentaje de extranjeros residentes que registran los censos es relativamente bajo. De todos modos, sería interesante examinar más a fondo la evolución de estas tendencias en la década de 1990, a medida que se vaya disponiendo de datos censales más recientes. 


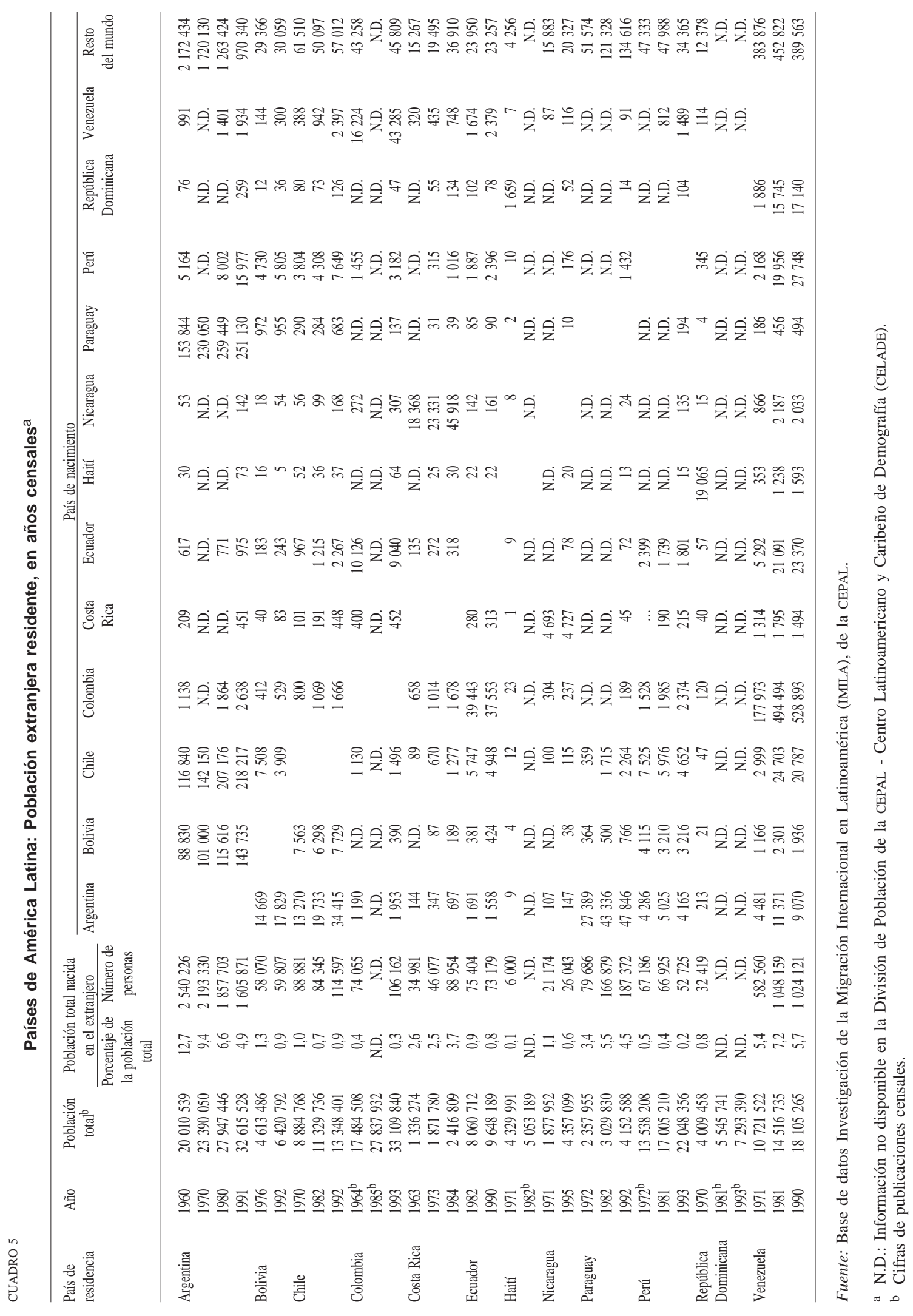


b) Remesas de fondos al país de origen efectuadas por los migrantes

La emigración, es decir, el desplazamiento físico de personas hacia el extranjero, tiene como contrapartida financiera los envíos de dinero de estas personas a su país de origen. Esto pone de relieve que la emigración en sí no representa únicamente costos para el país emisor, ya que el total de remesas que efectúan los migrantes constituye un beneficio que también tiene que ser puesto en la balanza. Las remesas que se dirigen a América Latina son cuantiosas: se ha estimado que en 2002 las enviadas a esta región totalizaron 32.000 millones de dólares (FOMIN, 2003). Esta cifra cobra mayor significación si se considera que la inversión extranjera directa (IED) hacia América Latina ese año ascendió a unos 39.000 millones de dólares, y las transferencias oficiales a la región sumaron unos 3.000 millones (CEPAL, 2002). En promedio, la participación de las remesas en el PIB de 14 países latinoamericanos en 2001 alcanzó al $8,5 \%$, con grandes diferencias de un país a otro. Las remesas representaron un 24,5\% en Haití, $17 \%$ en El Salvador, $15 \%$ en Jamaica y $9 \%$ en Ecuador, mientras que significaron menos de $3 \%$ en Perú, Colombia, México y Brasil. Como proporción de las exportaciones, las remesas respectivas equivalieron a más de $150 \%$ en Haití, $80 \%$ en Nicaragua, $60 \%$ en El Salvador y $20 \%$ en Ecuador (cuadro 6). Es necesario señalar que las remesas efectivas posiblemente superan las cifras anotadas, ya que el dinero a menudo se envía por vías informales (a través de amigos y parientes) y mediante transacciones que no se registran. El efecto macroeconómico y de desarrollo de las remesas es favorable, pues ellas complementan el ahorro interno. Además, los receptores de remesas generalmente son familias de bajos ingresos en los países de origen de los migrantes (Solimano, por publicarse).

CUADRO 6

América Latina y el Caribe: Remesas de los migrantes recibidas en 2001

\begin{tabular}{|c|c|c|c|}
\hline \multirow[b]{2}{*}{ País } & \multicolumn{3}{|c|}{ Remesas } \\
\hline & En millones de dólares & $\begin{array}{c}\text { Como porcentaje } \\
\text { del PIB }\end{array}$ & $\begin{array}{l}\text { Como porcentaje } \\
\text { de las exportaciones }\end{array}$ \\
\hline México & 9273 & 1,7 & 6,5 \\
\hline Brasil & 2600 & 0,4 & 4,0 \\
\hline El Salvador & 1920 & 17,0 & 60,0 \\
\hline República Dominicana & 1807 & 10,0 & 27,0 \\
\hline Ecuador & 1400 & 9,0 & 20,0 \\
\hline Jamaica & 959 & 15,0 & 30,0 \\
\hline Cuba & 930 & 5,0 & 40,0 \\
\hline Perú & 905 & 1,7 & 10,6 \\
\hline Haití & 810 & 24,5 & 150,0 \\
\hline Colombia & 670 & 0,0 & 2,4 \\
\hline Nicaragua & 610 & 22,0 & 80,0 \\
\hline Guatemala & 584 & 3,1 & 16,0 \\
\hline Honduras & 460 & 7,5 & 17,0 \\
\hline Bolivia & 103 & 1,3 & 6,7 \\
\hline Total y promedios & $23031^{a}$ & $8,5^{b}$ & $33,6^{b}$ \\
\hline
\end{tabular}

Fuente: (FOMIN 2003). Los Bancos Centrales brindaron la información sobre México, Centroamérica y el Caribe.

Las cifras para los países sudamericanos (Bolivia, Colombia y Ecuador) probablemente son inferiores a las reales.

a Total de los países.

b Promedio de los países. 


\section{III}

\section{Factores que determinan la migración internacional}

Habiendo examinado las tendencias de la migración mundial y regional hacia y desde América Latina a través de diferentes períodos históricos, consideraremos ahora los principales factores económicos que determinan la migración, así como otros temas conexos.

\section{Factores económicos de la migración interna- cional}

Un motivo principal para migrar es la expectativa de obtener en el extranjero mejores ingresos que en el país de origen. Hay otras variables que también influyen de manera importante en la decisión de emigrar, como la fase del ciclo económico, la existencia de redes sociales de apoyo a los migrantes, las políticas migratorias y los costos de migrar, los conflictos bélicos, la discriminación étnica y la persecución política en el país de origen. ${ }^{8}$

La magnitud y la dirección de las migraciones internacionales a menudo dependen de varios factores que se enumeran a continuación.

a) Diferencias de ingreso per cápita (o de salario real) entre el país de origen y el país receptor

Los flujos de migración neta, es decir, la inmigración menos la emigración, están asociados positivamente al cociente entre el ingreso real per cápita (o salario real) en el país de destino y el ingreso real per cápita (o salario real) en el país emisor. ${ }^{9}$ Tenien-

\footnotetext{
${ }^{8}$ Las ecuaciones de migración habitualmente incluyen las siguientes variables explicativas de la tasa de migración: la razón entre el salario real (o ingreso real per cápita) en el país de origen y en el país de destino; una variable de migración rezagada en un período, que refleja los efectos de la presencia de amigos y parientes (redes sociales) en el país de destino; una variable demográfica con un rezago de dos décadas que representa el crecimiento de la población en el país de origen, y una variable que señala el grado de industrialización de ese país (O’Rourke y Williamson, 2000).

9 Véase en Hatton y Williamson (1998, caps. 3 y 4) un examen detallado del efecto de las diferenciales de ingresos per cápita entre países sobre las corrientes migratorias de Europa al Nuevo Mundo a fines del siglo XIX y principios del XX. El rol de las diferenciales de ingreso per cápita en los flujos migratorios desde y hacia Argentina se examinan en la sección IV y en Solimano (2003).
}

do en cuenta la incertidumbre, la variable relevante es el ingreso esperado en el lugar de destino en comparación con el ingreso esperado en el país de origen. En una especificación dinámica, intertemporal, la variable más pertinente es el valor presente de la diferencial de los flujos de ingresos relativos esperados entre el país receptor de los migrantes y el país de origen de éstos.

b) Etapa del ciclo económico y perspectivas económicas en el país emisor y el país receptor

Los inmigrantes tienen más probabilidades de conseguir trabajo cuando el crecimiento económico del país receptor es alto y hay escasez de mano de obra. En cambio, la probabilidad de que los migrantes obtengan empleo disminuye si el crecimiento es lento y el desempleo es alto. Mientras que la decisión de emigrar depende en gran medida de las diferencias de ingreso per cápita entre países, la elección del momento de emigración está relacionada con la etapa del ciclo económico en que se encuentran el país emisor y el receptor.

\section{c) Redes sociales de apoyo}

Un análisis empírico de las corrientes migratorias (Hatton y Williamson, 1998; Borjas, 1999) muestra que a la hora de elegir un país de destino los migrantes tienden a valorizar mucho la presencia de amigos y parientes en un determinado país extranjero. Las redes de familiares, amistades, compatriotas y miembros de su mismo grupo étnico pueden actuar como sistema de apoyo, brindándole además al inmigrante información sobre empleos y demás datos importantes de la nación que lo recibe y facilitando así la adaptación individual y familiar necesaria luego de la migración.

\section{d) Políticas de inmigración}

Las políticas de inmigración restrictivas en los países receptores tienden a disminuir las corrientes migratorias hacia los países que las aplican, aunque siempre subsista cierta inmigración ilegal en algunos 
países. ${ }^{10}$ En este sentido, es válido hacer una distinción entre el deseo de inmigrar y la capacidad de inmigración.

\section{e) Costos de la migración}

Estos costos comprenden los gastos de desplazamiento, pasajes (aéreos u otros), transporte de bienes y sustento en el país de destino, además del costo de la búsqueda de trabajo. Suelen afectar de manera particular a las personas pobres y no calificadas, y a menudo constituyen un factor que inhibe su migración internacional. En general, no son los más pobres los que emigran a otros países, pues no pueden financiar los costos de hacerlo.

\section{f) Diferencias culturales entre países}

Factores como el idioma, las tradiciones y las relaciones familiares inciden en los patrones de migración. Las diferencias en estos rasgos culturales que suelen darse entre los países de origen y de destino tienden a actuar como un posible freno a la migración internacional.

\section{g) Distancia o proximidad geográficas}

En general, la migración hacia países limítrofes o cercanos tiende a ser más alta que hacia aquellos más lejanos: la geografía afecta la dirección y el caudal de las corrientes migratorias.

\section{Regímenes políticos y migración internacional}

Las corrientes migratorias entre países no dependen únicamente de determinantes económicos. Los regímenes políticos - democráticos o autoritarios - de los países emisores y receptores también pesan en la decisión de migrar. En general, las personas preferirán vivir en un país donde se respeten las libertades civiles y los derechos individuales (la libertad de opinión, de asociación y de culto, el derecho a la justicia y a elegir a las autoridades públicas) y se protejan los derechos eco-

\footnotetext{
${ }^{10}$ Véase en Chiswick y Hatton (2002) un interesante análisis de las políticas de inmigración en los países receptores.
}

nómicos (derechos de propiedad y garantías de cumplimiento de los contratos). Esto sucede más a menudo en las democracias que en las dictaduras, pues estas últimas tienden a restringir los derechos individuales. ${ }^{11}$ Albert Hirschman, en su clásica obra Salida, voz y lealtad, distingue entre las decisiones puramente económicas y la acción colectiva, lo que resulta útil para comprender los motivos económicos y políticos de la migración. Mientras que "la salida" es a menudo una decisión económica, "la voz" está en el campo de la acción colectiva o política (Hirschman, 1977). En este marco analítico, es posible que los individuos que se encuentren insatisfechos o descontentos con las condiciones económicas y políticas imperantes en su país, pero que en éste "la voz" (es decir, la acción colectiva) no tenga la capacidad de cambiar las cosas, elijan dejar el país, o sea, emigrar. Por lo tanto, en la emigración voluntaria (distinta de la de refugiados y asilados, que son emigrantes forzosos) también influye la percepción que tengan los nacionales o los extranjeros residentes de la calidad del régimen político en el país de residencia o de destino. Esto sugiere la existencia de una relación directa entre la emigración de nacionales o repatriación de extranjeros y la presencia de regímenes autoritarios que restringen derechos políticos y libertades civiles. Hay muchos ejemplos al respecto en América Latina: al establecimiento de gobiernos militares en Argentina en los decenios de 1960 y 1970, que coartaron las libertades civiles e intervinieron las universidades, suprimiendo la autonomía académica, le siguió un éxodo masivo de profesionales y científicos, una fuga de cerebros que tuvo efectos nocivos en el país. Algo similar ocurrió en Brasil en los mismos años, y en Chile en las décadas de 1970 y 1980 con regímenes autoritarios de esos períodos. En estos casos la emigración, a menudo de personas con un acervo de capital humano, fue la respuesta individual frente a regímenes políticos no democráticos que atropellaron los derechos civiles.

\footnotetext{
11 Véase en Olson (2000) un esclarecedor examen de las consecuencias económicas de democracias y autocracias.
} 


\section{IV}

\section{De receptor neto a emisor neto de migrantes: Argentina en el siglo XX}

\section{La evolución económica y política argentina}

En el curso del siglo XX la economía argentina, que se hallaba entre las seis más desarrolladas del mundo a fines del decenio de 1920, descendió hasta llegar en el último cuarto del siglo a ser una economía de ingresos medios entre aquellas en desarrollo. Como resultado, el país que de 1870 a 1950 había sido "importador" neto de población, principalmente desde Europa en las últimas décadas del siglo XX, se transformó en "exportador" neto, en muchos casos de personas con elevado nivel educativo.

El desarrollo económico argentino pasó por diversas etapas y ciclos y, con el correr del tiempo, comenzó a quedarse atrás de la evolución exhibida por las economías de mejor desempeño a nivel mundial. El período de 1870 a 1914, que los especialistas en historia de la economía han denominado la belle époque argentina, ${ }^{12}$ se caracterizó por una rápida expansión económica, abundante afluencia de capital extranjero y, como ya se mencionó, una inmigración masiva de europeos, sobre todo italianos y españoles, que representaron casi el $80 \%$ de las personas que llegaron al país (Bunge y Garcia Matta, 1929). En este período, que coincidió con la primera fase de globalización, ${ }^{13}$ la economía argentina crecía a una tasa de $6 \%$ anual y su ingreso per cápita superaba en 33\% al de España y $38 \%$ al de Italia (cuadro 7).

Como se indicó anteriormente, las políticas de inmigración argentinas apuntaban de manera activa a captar inmigrantes en el extranjero. A mediados del siglo XIX, el gobierno instaló oficinas de reclutamiento de inmigrantes en España e Italia, a los que se les pagaba el costo del traslado, se les proveía de alojamiento y se les otorgaban tierras; esta estrategia contribuyó a la afluencia masiva de personas al país en 1870-1914.

En ese período, la inmigración neta (inmigrantes menos emigrantes) en Argentina fue en promedio de unas 57.000 personas por año, siendo la tasa de alrede-

12 Véase Diaz Alejandro (1970), Bunge y Garcia Matta (1929), Cortés Conde (1979), Taylor (1994b) y Solberg (1978).

13 Véase Della Paolera (1994). dor de 15 por mil (cuadro 7). Las cifras disminuyeron en los primeros años de entreguerras (de 1914 a 1929), hasta situarse en 40.000 inmigrantes netos anuales, alrededor de la mitad de la cifra alcanzada entre 1900 y 1914. En esos años la economía mundial enfrentó graves problemas y la de Argentina no estuvo inmune a tal situación. La desarticulación de los mercados mundiales de capital y las perturbaciones en los mercados importadores europeos restringieron el acceso del país a los recursos financieros provenientes del exterior y redujeron sus mercados de exportación. ${ }^{14}$ Las corrientes migratorias obedecían al efecto combinado de la merma de oportunidades económicas en España e Italia, y de la abundancia de tierras, la escasez de mano de obra y el auge de la industria de exportación de cereales y carne, orientada sobre todo al mercado inglés que existía en Argentina. Los capitales extranjeros proporcionaban los recursos necesarios para construir y modernizar la infraestructura, como vías férreas, puertos y carreteras, y la inmigración brindaba la mano de obra y la capacidad empresarial esenciales para aprovechar estas oportunidades.

La década de 1930 fue negativa para la economía argentina; el crecimiento del PIB sólo alcanzó una tasa anual de $1,5 \% .{ }^{15}$ Como en otras economías de América Latina en esa época, Argentina adoptó a comienzos del decenio una estrategia de desarrollo hacia adentro, con un aumento de los impuestos a la importación de bienes intermedios y de capital. ${ }^{16} \mathrm{La}$ desaceleración de la economía redujo abruptamente la corriente inmigratoria neta hacia el país a unos 22.000 inmigrantes anuales entre 1930 y 1940. Después de la segunda guerra mundial, la migración europea hacia Argentina se

\footnotetext{
14 Véase Della Paolera y Taylor (1997).

${ }^{15}$ Para un análisis del impacto de las perturbaciones externas sobre Argentina en el decenio de 1930 y la reacción del país en materia de políticas, véase Della Paolera y Taylor (1998) y Diaz-Alejandro (1970).

${ }^{16}$ Diaz-Alejandro (1970) y Taylor (1994a) han demostrado que la política de sustitución de importaciones adoptada en Argentina en el decenio de 1930 contribuyó de manera significativa a elevar el precio relativo de los bienes de capital en el país, desalentando la formación de capital y el crecimiento.
} 


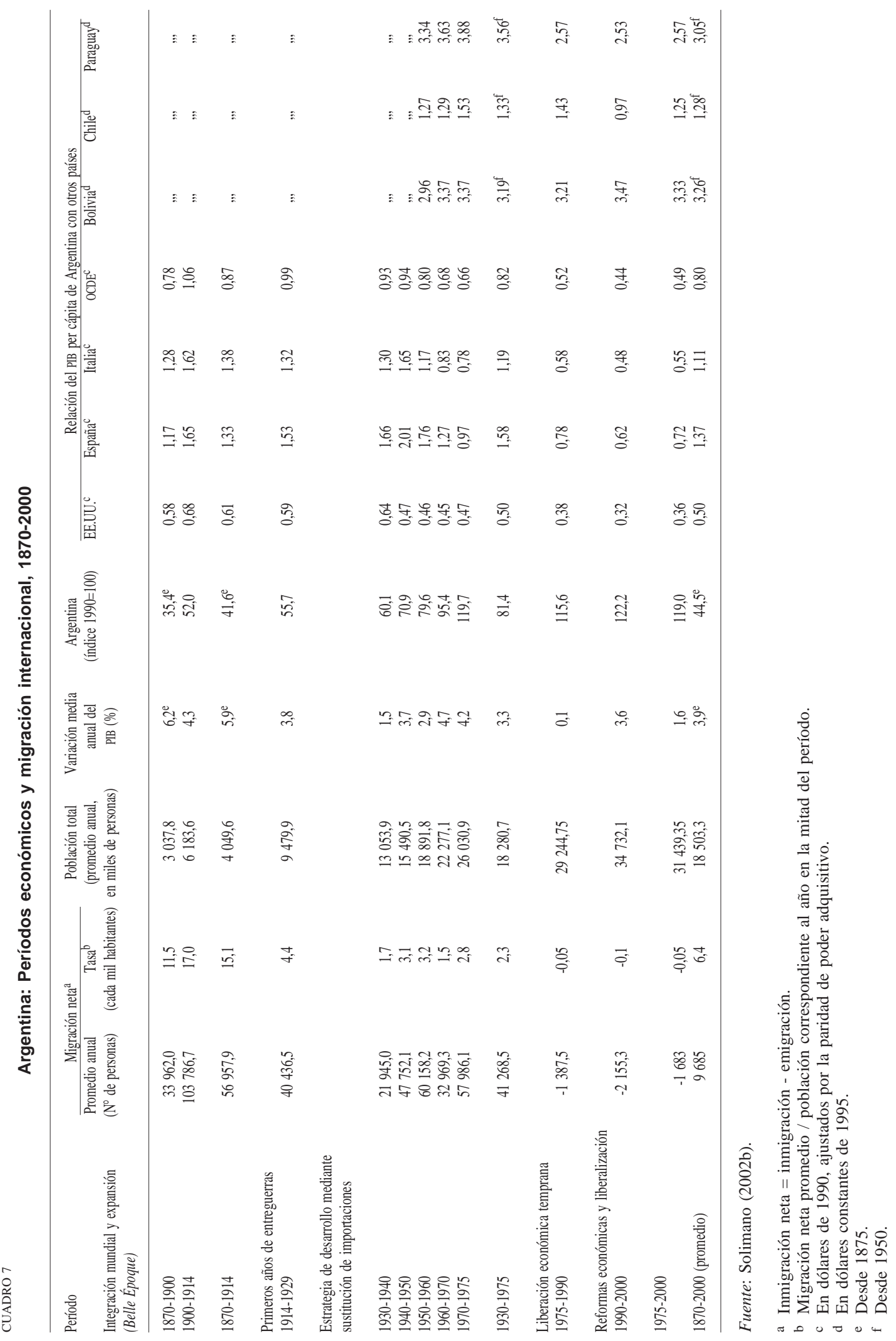


reanudó y se prolongó hasta mediados del decenio de 1950. La devastación humana y económica provocada por esa guerra impulsó a los europeos a abandonar sus países de origen, y Argentina resultaba ser un destino natural para emigrar, dados los vínculos previos generados y el conocimiento del país adquirido durante las grandes olas migratorias de fines del siglo XIX y principios del XX.

Sin embargo, la rápida recuperación económica europea de posguerra, en los últimos años de la década de 1940 y en la de 1950, sumada al rezago económico argentino, que acortó cada vez más la diferencia de ingresos per cápita entre el país sudamericano y los países europeos, pronto redujo los incentivos para la migración de Europa a Argentina, que sufrió una marcada disminución en el decenio de 1960 (cuadro 7) y casi desapareció en los de 1970 y 1980. ${ }^{17}$

Coincidiendo con la baja de la migración de Europa a Argentina, en la década de 1950 aumentó la inmigración procedente de los países vecinos. Como se mencionó en la sección II, se trató de corrientes considerables, compuestas sobre todo por trabajadores rurales o mano de obra urbana no calificada procedentes de Paraguay, Bolivia y Chile. ${ }^{18}$ Además de este cambio en los países emisores de los migrantes a Argentina, a partir de la década de 1930 se había producido dentro del país una importante migración desde las áreas rurales hacia las urbanas, asociada a la industrialización sustitutiva de las importaciones, la ampliación del aparato gubernamental y un proceso de urbanización cada vez más extenso. Los migrantes originarios de los países cercanos pasaron a desempeñar las tareas rurales que abandonaban los trabajadores argentinos en su desplazamiento hacia las ciudades. Otra tendencia importante que caracterizó las décadas de 1950, 1960 y 1970 fue la emigración de argentinos, sobre todo de ciudadanos altamente preparados, científicos e intelectuales. ${ }^{19}$ Razones fundamentales para esta emigración fueron, además de la contracción económica, la política de los gobiernos de Perón de exclusión de los intelectuales y profesionales no peronistas, en la década de 1950, y la abierta hostilidad de los

\footnotetext{
${ }^{17}$ Como resultado, entre 1975 y 2000 el PIB per cápita de Argentina fue en promedio $72 \%$ del de España y $55 \%$ del de Italia (cuadro 7 ).

18 Los paraguayos y los bolivianos se dirigieron en su mayoría al norte argentino, y los chilenos sobre todo a las haciendas del sur y a los yacimientos petrolíferos de la Patagonia.

19 Véanse estadísticas sobre la emigración de médicos, ingenieros, científicos y técnicos argentinos a los Estados Unidos entre 1950 y 1970, en Lattes, Oteiza y Graciarena (1986).
}

regímenes militares al disenso en las universidades, durante los decenios de 1960 y 1970. Esta situación culminó en forma dramática en 1967, durante el gobierno del general Juan Carlos Onganía, cuando la sola intervención gubernamental de la Universidad de Buenos Aires significó la expulsión de 1.305 académicos (Lattes, Oteiza y Graciarena, 1986). A esto le siguió una fuga de cerebros: los intelectuales empezaron a abandonar la Argentina, ante la amenaza de perder su empleo, y posiblemente su libertad, y ante el recorte de presupuestos universitarios que frenó los progresos en la investigación científica y la labor docente. ${ }^{20}$ Luego del intervalo de un gobierno democrático a principios de la década de 1970, la situación volvió a empeorar tras el golpe militar de 1976. El régimen, en un intento por consolidarse, llevó a cabo una estrategia generalizada de represión de cualquier opositor potencial, que incluyó la "depuración" masiva de los medios científicos, profesionales y estudiantiles. ${ }^{21}$

\section{Estimaciones econométricas}

La combinación de una economía estancada e inestable con ciclos de autoritarismo político hicieron que Argentina se convirtiera, en el último cuarto del siglo $\mathrm{XX}$, en un emisor neto de migrantes al resto del mundo. El crecimiento errático y la inestabilidad macroeconómica imperantes desde el decenio de 1950, que se revirtieron de manera parcial y transitoria en parte de la década de 1990, desvirtuaron claramente los fuertes incentivos económicos para emigrar a Argentina que existían a fines del siglo XIX y principios del XX. Además, gobiernos nacionalistas y populistas y regímenes militares represivos contribuyeron a desalentar la migración procedente de Europa ${ }^{22}$ y, como ya se señaló, los regímenes militares ${ }^{23}$ empujaron a gran número de las personas más educadas, y por lo tanto con

\footnotetext{
${ }^{20}$ El caso de César Milstein es ilustrativo: este ilustre científico argentino emigró de su país, trabajó para la Universidad de Cambridge y recibió, al cabo de unos años, el premio Nobel en el extranjero.

${ }^{21}$ El hecho de que las autoridades militares dejaran prácticamente de llevar registro de los argentinos que abandonaron el país entre 1976 y 1981 representa una dificultad empírica para la comprensión de la incidencia de los acontecimientos de la época sobre las corrientes migratorias.

${ }^{22}$ Aparentemente estos rasgos políticos de Argentina no frenaron la migración procedente de Bolivia o Paraguay, países que tenían su cuota propia de regímenes autoritarios.

${ }^{23}$ De comienzos de la década de 1930 hasta comienzos de la de 1980, Argentina tuvo una historia de considerable inestabilidad política y frecuente alternancia de regímenes democráticos y autoritarios. La sustitución de regímenes democráticos por dictatoriales
} 
mayor movilidad, a abandonar el país en diferentes momentos en el transcurso de la segunda mitad del siglo XX.

En Solimano (2003) se hace una estimación econométrica de los determinantes económicos y políticos de la inmigración neta en Argentina a lo largo del siglo XX, para varios subperíodos ${ }^{24} \mathrm{y}$ para todo el período 1990-1999. Los principales resultados de ese estudio se pueden resumir como sigue:

i) La diferencia de ingresos per cápita entre Argentina y los países de origen (sobre todo europeos hasta mediados del decenio de 1950, y con posterioridad Paraguay, Bolivia y Chile) ha tenido un efecto estadísticamente significativo sobre las corrientes de migración neta (inmigración menos emigración) desde y hacia la Argentina. Los resultados econométricos muestran que la brecha entre los ingresos per cápita de Argentina y de los países emisores de migrantes es un determinante robusto de la migración neta en los diferentes subperíodos del siglo XX, lo que confirma también el importante papel de las diferencias relativas de ingresos como causa de la migración internacional, que se analizó en la sección III.

ii) Los resultados econométricos también muestran un efecto estadístico negativo significativo de los gobiernos autoritarios sobre las corrientes de inmigración a la Argentina (y positivo sobre las corrientes de emigración desde este país), lo que confirma la gravitación de los regímenes políticos, más concretamente de la supresión de las libertades civiles y académicas y la violación de los derechos humanos por parte de las dictaduras, sobre la decisión de emigrar. Este factor parece influir en mayor medida en la población calificada y poseedora de un importante acervo de capital humano, que es más móvil y puede migrar hacia otros países.

\section{V}

\section{Observaciones finales}

En este artículo se ilustra cómo la migración internacional floreció durante la primera fase de globalización, desde cerca de 1870 a 1913, en concordancia con la progresiva integración de los mercados de capital y de bienes en el marco de una economía global abierta y con un sistema monetario basado en el patrón oro. Esta situación llegó a su fin durante el período de desglobalización que se extendió desde 1914 hasta mediados y más de la década de 1940. Este período abarcó dos guerras mundiales, la inestabilidad macroeconómica de los años veinte, la depresión de los treinta y turbulencias políticas recurrentes, todo lo cual creó un clima conducente a regímenes de migración internacional más restrictivos.

La segmentación de los mercados internacionales de trabajo se ha mantenido en la segunda fase de globalización, de 1970 en adelante, con políticas de inmigración restrictivas, sobre todo para la mano de obra no calificada, en las economías más desarrolladas. Sin embargo, el avance de la globalización de capitales y bienes se ha traducido en un enorme au-

empezó con la dictadura de José Uriburu en 1930 — que remplazó al gobierno democrático de Hipólito Irigoyen-y terminó con la del general Galtieri en 1983, a la que sucedió el presidente demo- mento de la movilidad internacional de las personas más calificadas y con altos niveles educativos (profesionales, expertos en informática, inversionistas internacionales).

La migración internacional desde y hacia América Latina ha dependido principalmente de las diferencias entre los ingresos per cápita de esta región y del resto del mundo. También la migración intrarregional ha reflejado las disparidades de los ingresos por habitante entre países dentro de América Latina. México y otros países de Centroamérica y el Caribe han sido los principales países de origen de la migración de sur a norte hacia los Estados Unidos. En el pasado, en la era de la migración masiva de fines del siglo XIX y principios del XX, Argentina fue un importante país de destino de la mano de obra migrante europea. Sin embargo, a medida que el crecimiento económico argentino se desaceleraba y se hacía más inestable a partir de la década de 1930, las oportunidades para los migrantes que venían de Europa disminuyeron y a fines de la década de 1950 la migración europea

cráticamente electo Raúl Alfonsín, que inauguró un ciclo de gobiernos democráticos que lleva unos 20 años.

${ }^{24}$ Los resultados de las regresiones se presentan en el anexo A. 
prácticamente desapareció. Fue sustituida por migraciones desde países vecinos en los que el ingreso per cápita era menor, principalmente Paraguay y Bolivia. En la segunda mitad del siglo XX, Argentina se convirtió también en un país emisor de migrantes, sobre todo de profesionales y personas con amplias calificaciones, cuando a la crónica inestabilidad económica se le sumó el autoritarismo político, especialmente en las décadas de 1960 y 1970.
Un análisis econométrico de los patrones de migración hacia y desde Argentina a través del tiempo muestra el peso que tuvo la diferencia de ingresos entre Argentina y los países emisores sobre la tasa de migración neta de este país sudamericano. Este resultado se cumple en varios subperíodos del siglo XX. Del análisis empírico también se deduce el impacto negativo de los regímenes autoritarios sobre la inmigración neta, que ya hemos mencionado, el que empobreció el capital humano de Argentina.

\section{Recuadro \\ CONSTRUCCIÓN DE LAS VARIABLES}

Tasa de migración neta

Inmigración menos emigración por cada mil habitantes.

PIB per cápita de Argentina

En millones de dólares de 1990 ajustados por la paridad del poder adquisitivo (según el método de GearyKhamis) / población de Argentina en miles de habitantes, a mitad de año.

PIB per cápita de Europa

En millones de dólares de 1990 ajustados por la paridad del poder adquisitivo (según el método de GearyKhamis) / población en miles de habitantes, a mitad de año.

i) PIB per cápita de Europa $(1900-1929,1900-1999)=1 / 3$ [1/6 (PIB per cápita de Austria + PIB per cápita de Bélgica + PIB per cápita de Francia + PIB per cápita de Alemania + PIB per cápita de Suiza + PIB per cápita del Reino Unido) $]+1 / 3$ PIB per cápita de España $+1 / 3$ PIB per cápita de Italia.

El cambio en las ponderaciones refleja la disminución de la importancia de España e Italia como países de origen de la migración a Argentina.

ii) PIB per cápita de Europa (1929-1960, 1960-1999) = 1/8 [PIB per cápita de Austria + PIB per cápita de Bélgica + PIB per cápita de Francia + PIB per cápita de Alemania + PIB per cápita de Suiza + PIB per cápita del Reino Unido + PIB per cápita de España + PIB per cápita de Italia].

PIB per cápita de los países vecinos de Argentina

En millones de dólares de 1995 / población en miles de habitantes, a mitad de año.

El PIB per cápita (1950-2000) de los países vecinos de Argentina = 1/3 [PIB per cápita de Bolivia + PIB per cápita de Chile + PIB per cápita de Paraguay].

Índice cíclico del PIB

Cociente entre el PIB de Argentina y el PIB tendencial de Argentina, ambos en millones de dólares de 1990 ajustados por la paridad de poder adquisitivo (según el método de Geary-Khamis).

El PIB tendencial de Argentina se calculó empleando el filtro de Hodrick-Prescott.

Índice del régimen político

Variable ficticia, en la que 1 significa régimen autoritario.

(Traducido del inglés) 


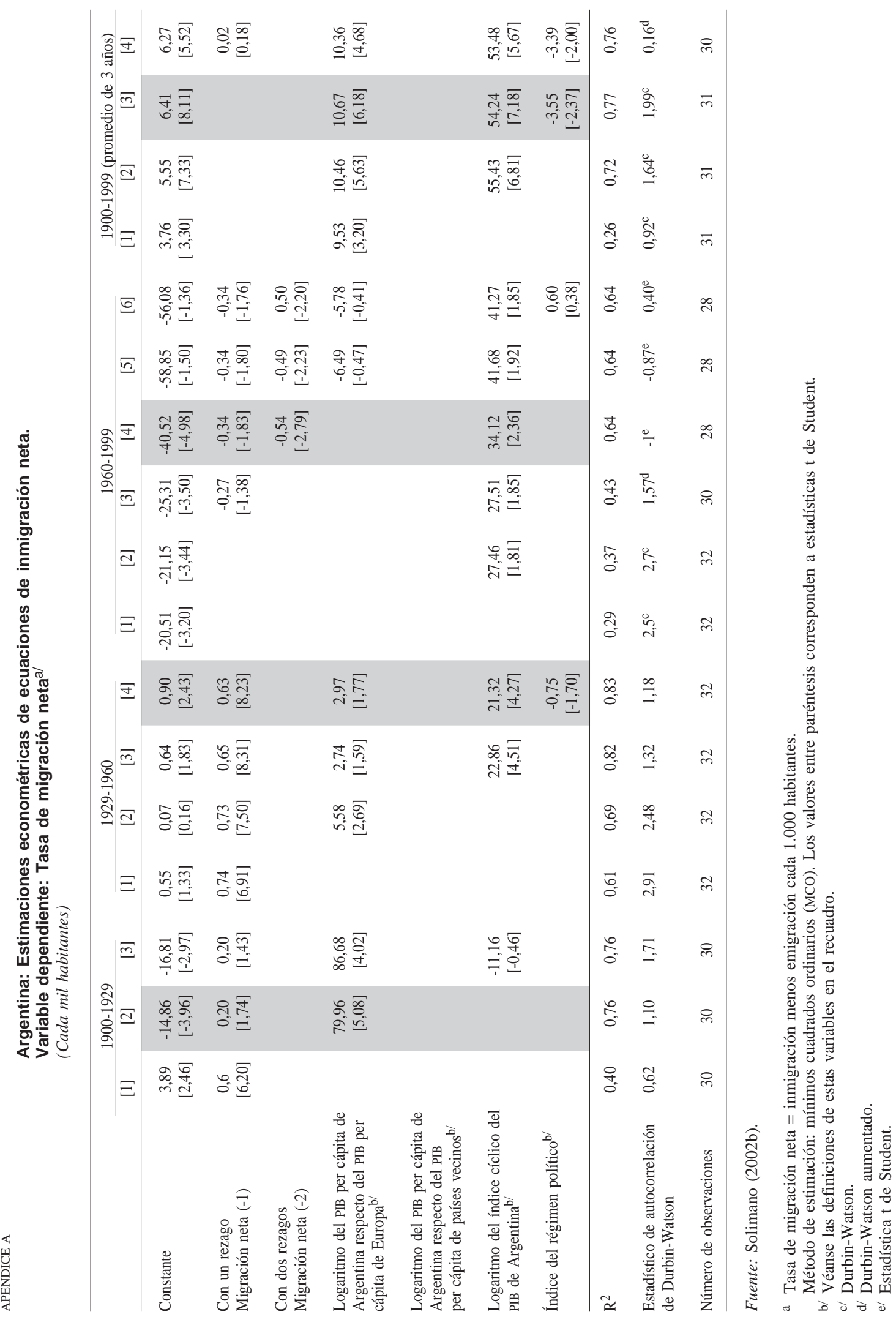




\section{Bibliografía}

Abella, M. (1997): Sending Workers Abroad, Ginebra, Oficina Internacional del Trabajo (OIT).

Adams, W. (comp.) (1964): The Brain Drain, Nueva York, The Macmillan Company.

Borjas, G. (1999): Heaven's Door. Immigration Policy and the American Economy, Princeton, Princeton University Press.

Bunge, A. y C. Garcia Matta (1929): Argentina, en I. Ferenczi y W. Wilcox, International Migrations, Cambridge, Massachusetts, National Bureau of Economic Research (NBER).

Carrington, W. y E. Detragiache (1998): How Big is the Brain Drain?, IMF Working Paper, No 98/102, Washington, D.C., Fondo Monetario Internacional.

CEPAL (Comisión Económica para América Latina y el Caribe) (2002): Globalización y desarrollo, LC/G.2157(SES.29/3), Santiago de Chile, mayo.

Chiswick, B. y T. Hatton (2002): International migration and the Integration of Labor Markets, en M. Bordo, A.M. Taylor y J. Williamson (comps.), Globalization in Historical Perspective, Chicago, Chicago University Press.

Cortés Conde, R. (1979): El proceso económico argentino, Buenos Aires, Editorial Sudamericana.

Della Paolera, G. (1994): Experimentos monetarios y bancarios en Argentina: 1861-1930, Revista de historia económica, año XII, $\mathrm{N}^{\mathrm{o}}$ 3, Madrid, Universidad Carlos III.

Della Paolera, G. y A. Taylor (1998): Economic Recovery From the Argentine Great Depression: Institutions, Expectations and the Change of Macroeconomic Regime, NBER Working Paper, $\mathrm{N}^{\circ}$ 6767, Cambridge, Massachusetts, National Bureau of Economic Research.

(1997): Finance y Development in an Emerging Market: Argentina in the Interwar Period, NBER Working Paper, $\mathrm{N}^{\circ}$ 6236, Cambridge, Massachusetts, National Bureau of Economic Research, octubre.

Diaz-Alejandro, C.F. (1970): Essays on the Economic History of the Argentine Republic, New Haven, Yale University Press.

Eichengreen, B. (1996): Globalizing Capital. A History of the International Monetary System, Princeton, Princeton University Press.

FOMIN (Fondo Multilateral de Inversiones (2003): Sending Money Home: An International Comparison of Remittances Markets, Washington, D.C., Banco Interamericano de Desarrollo (BID).

FMI (Fondo Monetario Internacional) (varios años): International Financial Statistics, Washington.

Haque, N. y S. Kim (1994): Human Capital Flight: Impact of Migration on Income and Growth, IMF Working Paper, № 94/ 155, Washington, D.C., Fondo Monetario Internacional.

Hatton, T.J. y J.G. Williamson (1998): The Age of Mass Migration. Causes and Economic Impact, Nueva York, Oxford University Press.

Hirschman, A. (1977): Salida, voz y lealtad, México, D.F., Fondo de Cultura Económica.

Holloway, T.H. (1977): Immigration and abolition. The transition from slave to free labor in the São Paulo Coffee Zone, en D. Alden y W. Dean (comps.), Essays Concerning the Socioeco- nomic History of Brazil and Portuguese India, Gainesville, University Press of Florida.

Immigration and Naturalization Service (2000): 1998 Statistical Yearbook of the Immigration and Naturalization Service, Washington.

Lattes, A.E., E. Oteiza y J. Graciarena (1986): Dinámica migratoria argentina (1955-1984): democratización y retorno de expatriados, Ginebra, Instituto de las Naciones Unidas para el Desarrollo Social/Centro de Estudios de Población (CENEP).

Maddison, A. (1995): Monitoring the World Economy, 1820-1992, París, Organización de Cooperación y Desarrollo Económi$\cos$ (OCDE).

(2001): The World Economy. A Millennial Perspective, París, Organización de Cooperación y Desarrollo Económi$\cos$ (OCDE).

Olson, M. (2000): Power and Prosperity. Outgrowing Communist and Capitalist Dictatorships, Nueva York, Basic Books.

O'Rourke, K. y J. Williamson (2000): Globalization and History. The Evolution of a Nineteenth-Century Atlantic Economy, segunda edición, Cambridge, Massachusetts, The MIT Press.

Solberg, C.E. (1970): Immigration and Nationalism, Argentina y Chile, 1890-1914, Austin, University of Texas Press.

(1978): Mass migration in Argentina, 1870-1970, en W.H. McNeill y R.S. Adams (comps.), Human Migration, Patterns and Policies, Bloomington, Indiana University Press.

Solimano, A. (2001): International Migration and the Global Economic Order: An Overview, Working Paper, No 2720, Washington, D.C., Banco Mundial, noviembre.

(2002): Globalizing Talent and Human Capital: Implications for Developing Countries, serie Macroeconomía del desarrollo, No 15, LC/L.1773-P, Santiago de Chile, CEPAL. Publicación de las Naciones Unidas, $\mathrm{N}^{\mathrm{o}}$ de venta: E.02.II.G.87. (2003): Development Cycles, Political Regimes and International Migration: Argentina in the $20^{\text {th }}$ Century, serie Macroeconomía del desarrollo, CEPAL.

(por publicarse):Emigrants remittances as a source of development finance, documento presentado para el proyecto New sources of Development Finance, Helsinki, UNU-WIDER.

Stalker, P. (2000): Workers Without Frontiers. The Impact of Globalization on International Migration, Boulder, Colorado, Lynne Rienner Publishers, Inc.

Taylor, A. (1994a): Three Phases of Argentine Economic Growth, NBER Historical Working Paper, $\mathrm{N}^{\circ}$ 60, Cambridge, Massachusetts, National Bureau of Economic Research.

(1994b): Mass migration to distant shores: Argentina and Australia, 1870-1939, en T. Hatton y J. Williamson (comps.), Migration and the International Labor Markets, 1850-1939, Nueva York, Routledge.

Timmer, A. y J. Williamson (1996): Racism, Xenophobia or Markets? The Political Economy of Immigration Policy Prior to the Thirties, NBER Working Paper, N ${ }^{\circ} 5867$, Cambridge, Massachusetts, National Bureau of Economic Research. 